\title{
Reforming the House of Lords: navigating representation, democracy and legitimacy at Westminster $^{1}$
}

\author{
Dr Alexandra Kelso \\ ESRC Postdoctoral Fellow \\ Department of Government \\ 16 Richmond Street \\ University of Strathclyde \\ Glasgow G1 1XQ
}

Parliamentary Affairs (2006), vol.59, no.4, pp.563-581.

\begin{abstract}
Several schemes for reforming the House of Lords have been proposed since 1997, and each have made various claims about how they will contribute to a chamber that is more representative, more democratic and more legitimate. There has, however, been little analysis of how different actors have understood these terms, and of the conceptual confusion that has peppered their various reports. This article seeks to address this gap, and to explore the nature of the conceptual problems that have characterised the reform debate in recent years. It explores various documents that have informed the discussion over House of Lords reform - the Labour Party manifestos, the Royal Commission report, the government white paper, the Public Administration Committee report, the Joint Committee report - all of which have continued relevance in the context of the resuscitation of these deliberations following the 'loans for peerages' controversy in spring 2006.
\end{abstract}




\section{Introduction}

Since the Labour Party committed to reforming the House of Lords in its 1997 election manifesto, several schemes for reconstituting the second chamber have been promoted. Each scheme has made various claims for how it will produce a house that is more representative, more democratic and more legitimate than the present one. However, reformers have discussed these proposals with apparently limited understanding of the concepts involved and, more importantly, their relationship to each other. Ideas about representation, democracy and legitimacy have at times been muddled, with the three terms often used interchangeably, yet there has been no analysis of the extent of this conflation, or what it means for the reform debate. This article seeks to address the gap that exists in the literature by analysing the way in which these ideas have been used by various actors during the recent cycle of House of Lords reform, in order to uncover the nature and extent of the conceptual confusion that has pervaded the debate. Such analysis is particularly relevant in the context of the Labour government's 2005 manifesto commitment to continue with second chamber reform, a commitment that was renewed in 2006 amid controversy about the links between party funding and membership of the House of Lords.

\section{Representation, democracy and legitimacy}

The basic definition of representation seems straight-forward enough. For Pitkin, 'representation, taken generally, means the making present in some sense of something which is nevertheless not present literally or in fact'. ${ }^{2}$ The complexity of the term stems from the debate over the 'something' that is to be represented. As Judge explains, 'the simple overriding fact about parliamentary representation in Britain is that it is based on territory'. ${ }^{3}$ The constituency basis of representation, and its mediation through parties, 
lies at the heart of the evolution of parliamentary government at Westminster, and provides an organising framework around which the House of Commons functions. ${ }^{4}$ Other types of representation include associationalism, such as the guild socialism espoused by G.D.H. Cole, ${ }^{5}$ which aims to locate representation in the economic sphere and the workplace. In contrast, functional representation aims to have legislatures that are designed for specific functions, with representatives selected on the basis of their functional contribution. Winston Churchill's plan in the 1930s for an economic parliament geared towards addressing economic problems, and filled with members with an economic background, is one example of the functional approach to representation. ${ }^{6}$ Closely linked to both these types of representation is the issue of which of the population's characteristics should be represented. Microcosmic representation is concerned with the representativeness of an institution in relation to the population or electorate. Adherents of microcosmic representation argue that the decision-making capabilities of a legislature are directly affected by the extent to which it is a reflection of the wider population. ${ }^{7}$ This raises the question about which characteristics of an electorate are deemed important enough to find reflection in the representativeness of an institution. This kind of 'politics of presence' prioritises identity as the basis of representation, coupled with the argument that identities such as gender, race and ethnicity should enjoy enhanced inclusion inside representative institutions. ${ }^{8}$ There are, then, many different ways in which the population can be represented in the legislature, and it is clearly necessary to draw a distinction between representation and representativeness. In the context of parliamentary reform, the preferred form of representation, and the extent of any representativeness it entails, will ultimately be a product of the kind of chamber that actors wish to see emerge at the end of the reform process. 
The mechanism of representation facilitates the functioning of democracy in modern societies. It is through representative democracy that the population participates in the political process, but in a way that enables a division of labour between those who choose the decision-makers and those who are the decision-makers. As an 'indirect' form of democracy, representative democracy operates on the basis of exclusion, in that the vast majority of the population is excluded from the decision-making process. ${ }^{9}$ However, the crucial point is that they are excluded on the basis of the elections in which they participate. Hirst explains that 'limited participation is an institutional feature of mass democracy and not merely a failing due to specific circumstances. ${ }^{10}$ Judge comments that, "elections, by definition, are mechanisms for the selection of elites: but they are simultaneously mechanisms for mass participation'. ${ }^{11}$ The crucial point is that by moving beyond the simple notion of 'rule by the people', democracy, or more specifically, representative democracy, is instead about the nature of the political process. Representative democracy can be characterised as democratic 'by stipulating a cluster of institutions and rules which define the relationship between governed and governors in the determination of how representatives are chosen and how popular control is exercised over representatives. ${ }^{12}$ Several attempts have been made to stipulate what is meant by those 'cluster of institutions and rules'. For Sartori, they encompass limited majority rule, elective procedures, and the representational transmission of power. ${ }^{13}$ Dahl perceives a democratic process as incorporating effective participation, voting equality at the decisive stage, enlightened understanding on the part of citizens, and control of the agenda. ${ }^{14}$ Returning to Hirst, we find that democracy 'becomes a set of political mechanisms, of which representation through elections is one, that exercise constraints on government'. ${ }^{15}$ From these definitions, it is clear that for a political process to be called democratic, it must include a system of elections 
whereby the population can choose its representatives: it is through elections that the relationship between government and governed is defined, and mechanisms of control established. Elections are, therefore, a necessary, if not sufficient, condition for a system or institution to be termed 'democratic'.

There is an important point to stress here, and it is one that has been alternately confused and overlooked in the context of reforming the House of Lords. Political institutions may claim to be representative in one way or another, but that does not mean they will also be democratic. Similarly, an institution might be democratic, but it may not necessarily be representative, depending on which representational values are prioritised. For example, we may require an institution that is a microcosmic reflection of society, with particular regard to gender and ethnic identities. However, as is widely demonstrated across most democratic societies, a system of elections may not bring about such microcosmic representation. It may be that the goal is to have an institution comprised of representatives from different professions and in possession of a range of expertise; again, elections may not guarantee that outcome. Representative and democratic characteristics do not necessarily go hand in hand. It is therefore necessary for an institution, in addition to having representative and/or democratic qualities, also to be considered legitimate.

Political legitimacy has been explored extensively by David Beetham, and although his approach applied initially to the study of state power, it can also be applied to specific political institutions, as Beetham has done with reference to the EU. Beetham's analysis stemmed from the inadequacies of the Weberian approach to legitimacy, which maintained that power was legitimate because people believed it to be legitimate. ${ }^{16}$ Rather, power was legitimate 'because it can be justified in terms of [people's] beliefs.' ${ }^{17}$ A crucial observation is that legitimacy 'is not an all-or-nothing 
affair, but [is] a matter of degree. ${ }^{18}$ In its broadest sense, power is legitimate to the extent that: it conforms to established rules; the rules can be justified by reference to beliefs shared by both dominant and subordinate; and there is evidence of consent by the subordinate to the particular power relation. ${ }^{19}$ Beetham argues that, with regards to these three aspects of legitimacy, it is possible to examine the way in which it is (or is not) realized within specific institutions. ${ }^{20}$ For the first aspect of legitimacy, that of legality, one must look at the relationship between the different branches of the state. In terms of the second aspect, rule-justifiability, 'we need to examine the extent to which the basic rules of appointment to high office embody an accepted source of authority, and facilitate the acknowledged ends of government. ${ }^{21}$ With regards to expressed consent, "we must consider the form and extent of political participation. ${ }^{22}$ In liberal democratic societies, therefore, the three dimensions of state legitimacy are: 'performance in meeting the needs and values of citizens; public control with political equality; and a sense of identity without which the legitimacy of the unit will be contested, however impeccable its procedures. ${ }^{, 23}$ The first of these dimensions, performance in meeting the needs and values of citizens, is termed 'output' legitimacy, while the latter two are equivalent to 'input' legitimacy. ${ }^{24}$ For a given political institution, input legitimacy stems from the control exercised by the public in determining its nature and composition. Input legitimacy also derives from the political authorisation facilitated by this public control, and the identification and support it generates for the institution as a result. Output legitimacy flows from the way in which an institution performs its particular functions within the broader political system, and meets the needs of the public.

As with representation and democracy, there is a significant point about legitimacy and how it should be understood. An institution which is deemed to have 
input legitimacy may not also be considered to have output legitimacy, and vice versa. Legitimacy is not an all-or-nothing matter, and institutions must rather be considered to possess varying degrees of legitimacy. For example, in a society that places high value on democratic processes, an institution may only be deemed to be legitimate at the input stage if it involves a system of elections to determine its membership. Alternatively, if citizens value representativeness or expertise as characteristics in an institution, then it may only be deemed to have input legitimacy if its membership possesses such qualities. The public may wish an institution to have both democratic and representative qualities, and thus a particular balance has to be found in order for it to acquire an acceptable level of input legitimacy. In addition, the way in which input legitimacy is secured is likely to impact upon the probable levels of output legitimacy. What is crucial is that there is no magic formula for attaining a 'generic' legitimacy that pervades an institution, and it may also be unlikely that the public will prefer input legitimacy over output legitimacy, or vice versa. Ideally, the public may prefer to see an institution over which they exercise control, with which they identify, and which also meets high standards of performance: meeting such demands has long been the task of institutional designers. Nevertheless, the degree of input and output legitimacy that an institution is deemed to enjoy is determined with reference to the three dimensions of legitimacy. First, the extent to which the institution is constituted and operates according to agreed rules. Second, whether those rules are 'normatively justifiable according to beliefs current in society', to which there are two aspects: whether an institution's power 'derives from a rightful source of authority, and how this source is reflected in the rules of appointment to office'; and how it fulfils the various functions ascribed to it. ${ }^{25}$ Third, its 'rightfulness of authority' depends also on how the public accept the institution and endorse its actions. 
These three terms - representation, democracy and legitimacy - have countless volumes dedicated to their exploration, and the preceding discussion in no way attempts to delve into all the attendant complexities. Instead, it provides a conceptual springboard into the debate over House of Lords reform that has taken place since 1997, and facilitates analysis of the various reform schemes that have been forwarded. The aim is not to examine every plan that has been proposed, but to focus instead on the proposals that have had the most impact on the debate. These are: the 1997 Labour Party manifesto, the 2000 Royal Commission report, the 2001 government white paper, the 2002 Public Administration Committee report, and the 2002 Joint Committee report. Each of these reports discussed the issues of representation, democracy and legitimacy, and all engaged in varying degrees of conceptual conflation.

\section{The Labour Party Manifesto}

The Labour Party's 1997 election manifesto declared that '[t]he House of Lords must be reformed', and promised 'an initial, self-contained reform, not dependent on further reform in the future', that would remove the right of hereditary peers to sit and vote in the House of Lords. ${ }^{26}$ This was to be 'the first stage in a process of reform to make the House of Lords more democratic and representative'. ${ }^{27}$ Immediately there is evidence of the conceptual muddling that has taken place in the Lords' reform debate. The warning that no further stages of reform are promised indicates that, as far as the manifesto is concerned, the removal of the hereditary element, by definition, results in a more democratic and representative chamber. It suggests that an appointed House is more representative and democratic minus its hereditary peers, an argument that cannot withstand scrutiny. The House cannot be considered more democratic, because it would still lack the necessary condition of a system of elections for determining the 
membership. Furthermore, it cannot be any more representative than it was before, because there has been no reformulation of the representational basis of the chamber in terms of identifying which characteristics ought to enjoy representation. The manifesto made no attempt to explain exactly how the chamber would be more representative and democratic with its hereditary element removed, and did not explore either concept. These tasks were instead left to other actors. However, this manifesto comment regarding the desired nature of the reformed House of Lords had a continuing influence on the subsequent debate.

\section{The Royal Commission on Reform of the House of Lords}

The House of Lords Act 1999 removed the majority of the hereditary peers from the second chamber. While this legislation was being negotiated, a Royal Commission was established to pave the way for further change, and its report, A House for the Future, published in January 2000, affords an insight into how the Commission members conceptualised representation, democracy and legitimacy.

The Commission made the case for a second chamber that would be 'authoritative, confident, and broadly representative of the whole of British society. ${ }^{28}$ Interestingly, there is no specific mention of the chamber possessing a democratic characteristic. The Commission explained that ' $[\mathrm{t}]$ he reformed second chamber should be authoritative', but also that it 'should not be such as to challenge the ultimate authority of the House of Commons'. ${ }^{29}$ Such concerns lie at the heart of the reform debate: indeed, the requirement to preserve the maintenance of the House of Commons formed part of the Commission's terms of reference. Consequently, much of what the Royal Commission said about democracy and legitimacy was conditioned by the desire to ensure that the balance of power between the two parliamentary chambers remained intact. The report 
noted that, '[i]t does not follow that there can be no role for the electorate in choosing members of the second chamber', but that 'the greater the "democratic legitimacy" of the second chamber, the greater the risk of damaging constitutional conflicts arising between the two Houses of Parliament. ${ }^{30}$ The Commission insisted that if the democratic balance was tipped too far, there would be ramifications for the electoral authorisation bestowed by the House of Commons. While accepting that a democratic chamber necessarily implied an elected membership, the Commission maintained that it is 'an error to suppose that the second chamber's authority can only stem from democratic election. ${ }^{31}$ The report noted that authority can also be derived from the representativeness of the chamber, the experience, expertise and personal distinction of its members, their contribution to public debate and their ability to exercise judgement free from partisan considerations. By placing the emphasis on the respective contributions of input and output legitimacy, the Commission suggests that a democratic characteristic is just one of many kinds of input legitimacy, and that representativeness is just as important. Output legitimacy, by contrast, may be derived from the contributions that members make to the functional efficacy of the chamber and to public life in general. The Commission thus envisioned a chamber that derived its legitimacy, or authority as it was termed, from a 'wide range of sources', 32 an approach primarily designed to preserve the pre-eminence of the House of Commons.

The Commission had clear ideas about what it meant by a representative chamber, and how this contributed to its legitimacy. It argued that, '[t]he second chamber could gain significant strength and authority from being seen to be representative of British society in all its dimensions. ${ }^{, 33}$ In rejecting the idea of a chamber that was 'a mere statistical microcosm of British society', the Commission opted instead for one that contained regional representation, gender balance, ethnic and vocational representation, 
and representation for voluntary, cultural and other such organisations. This therefore drew on a range of different types of representation, including territorial and functional representation along with elements of microcosmic representation. The notion of having certain kinds of experience and expertise represented has particular functional importance, in that such individuals would be 'familiar with the broad issues in a given area ... know what questions to ask and how to interpret the answers. ${ }^{, 34}$ This functional representation would also be present through the inclusion of those with skills and knowledge of constitutional and human rights matters, and with philosophical, moral and spiritual perspectives. ${ }^{35}$ The Commission's primary reason for rejecting direct election was that it would lead to conflict with the House of Commons, but also because elections would impact upon the representative characteristics of the chamber. The report noted that 'most systems of direct election deliver results which may be geographically representative but which are seldom gender-balanced or provide appropriate representation for ethnic, religious or other minorities,' and further noted that '[d]irect elections are also not well suited to securing membership ... for those with specific expertise and authority in constitutional matters and the protection of human rights. ${ }^{, 36}$ Being thus well aware that a democratic institution is not necessarily a representative institution, the Commission prioritised the need for the latter over the former. It recommended that the majority of the chamber's membership be appointed, with a significant minority of elected 'regional members. ${ }^{37}$

With this approach, the Commission believed they would meet the Labour Party manifesto commitment to a more democratic and representative chamber. It claimed it would be more democratic, 'because the membership as a whole will reflect the balance of political opinion within the country as expressed at the most recent general election and because the "regional" members will be proportionally representative of political 
opinion within their respective regions.' The chamber would be more representative, 'because it will contain members from all parts of the country and from all walks of life, broadly equal numbers of men and women and representatives of all the country's main ethnic and religious communities. ${ }^{38}$ However, at this point, conceptual conflation has set in. While the Commission is accurate in explaining how its proposals would lead to a more representative institution, it provides a rather confused democratic justification. While previously stating that democratic legitimacy stems from elections, the Commission goes on to equate democracy with representation: it mistakenly claims that the chamber would be more democratic because the regional members would 'reflect the balance of political opinion' and be 'proportionally representative of political opinion'. For the chamber to be more democratic, there would have to be elections to select its membership, as elections are a necessary, if not sufficient, condition in any democratic institution. Yet the Commission did not directly argue that the inclusion of a specifically elected membership would fulfil the commitment to creating a more democratic chamber. Consequently, the democratic justification for the reform plan is somewhat problematical.

\section{The Government White Paper}

The government did not proceed with the recommendations of the Royal Commission, and instead published a white paper in November 2001 that outlined a slightly different approach to the question of composition. ${ }^{39}$ It noted four characteristics for the reformed chamber. ${ }^{40}$ First, it should be a revising and deliberating assembly. Second, its membership should be appropriate for those functions and not be a clone of the House of Commons. Third, it should have a political outlook, but not be dominated by any one party. Finally, the chamber should be representative of independent expertise in the UK. 
As with the Royal Commission proposals, the white paper did not specifically mention the chamber having democratic characteristics, which is notable considering the Labour Party repeated its reference to the need for a 'more democratic' chamber in its 2001 manifesto. ${ }^{41}$ The white paper's recommendations for composition were quite different to those of the Royal Commission. It proposed a chamber of 600 members, 120 of whom would be non-party members selected by the Appointments Commission, 120 would be directly elected, 332 would be nominated by the political parties, and the remainder would draw on the bishops and law lords. ${ }^{42}$ The government therefore not only advocated a smaller proportion of directly elected members than did the Royal Commission, but also recommended that the bulk of the nominated members should be chosen by the parties, not by an independent body.

The government's view of the purpose of representation in the second chamber was similar to that of the Royal Commission. The white paper made reference to the need for enhanced representativeness in the second chamber, arguing that 'representativeness should go beyond political affiliation to embrace faith, gender and ethnicity. ${ }^{43}$ To this microcosmic representativeness was to be added functional representation, with members included on the basis of their expertise and experience, 'to add a distinctive approach to [the chamber's] consideration of legislation, and to help it fulfil its more general scrutiny functions. ${ }^{44}$ Representational considerations were therefore seen as impacting upon the performance of the chamber and its output legitimacy. A house that was primarily nominated 'is best suited to securing a properly representative membership [and] able to fulfil the functions of the second chamber. ${ }^{45}$ The government rejected the view that only direct election could confer legitimacy on the second chamber, ${ }^{46}$ but nevertheless included a small proportion of elected members in the proposed composition. The difficulty arises in ascertaining why this small 
proportion was deemed necessary at all, particularly if the government believed the chamber would derive its input legitimacy from its representational and representative credentials, and its output legitimacy from the chamber's enhanced fulfilment of its various functions. The reason for including an elected element, said the white paper, was 'specifically to ensure that there is adequate regional representation. ${ }^{47}$ However, a desire to see regional representation is obviously an argument about the representational credentials of the chamber, and not about its democratic characteristics. Regional representation can be secured through nomination just as it can through election. The white paper thus engaged with the same conceptual conflation as did the Royal Commission, justifying a small proportion of elected members on the basis of the regional representation they would facilitate, when the inclusion of elected members should rather be justified with reference to democratic arguments. The government had already expressed its desire to see a 'more democratic' chamber, and yet it did not argue that the 120 elected members would result in such an outcome.

One reason why the government avoided justifying the elected members in terms of enhanced democracy was because of the controversy generated about whether or not such a small proportion of elected members could indeed make the chamber any more democratic. However, the reluctance to pursue any democratic justifications largely stemmed from the white paper's argument that, since the government was legitimated by means of elections to the House of Commons, any democratic justification for the second chamber would threaten the basis of that legitimacy, and, along with it, the primacy of the House of Commons. ${ }^{48}$ The white paper, like the Royal Commission report, was clear that the pre-eminence of the House of Commons had to be maintained, because it had 'provided Britain with effective democratic government and accountability for more than a century. ${ }^{49}$ Conflation of the terms democracy and 
legitimacy was therefore further exacerbated, as the discussion was largely determined by concerns about what democracy and legitimacy in the Lords would mean for democracy and legitimacy in the Commons.

\section{The Public Administration Committee}

The position taken by both the Royal Commission and the government - that elected members in the second chamber should form only a minority of the total composition has been challenged, notably by the Public Administration Committee, which published its report on the matter in February 2002. ${ }^{50}$ The Committee argued that 'those who advocate appointment need to understand that it raises serious problems about legitimacy' and that 'patronage is not regarded as an acceptable basis for a representative institution in a democracy,. ${ }^{51}$ The Committee further recognised that second chamber reform involved a delicate balancing act, stating that ' $[\mathrm{w}] \mathrm{e}$ want a second chamber that has enough institutional legitimacy to ensure that it is taken seriously, and enough independence and expertise among its membership to ensure that it is worth taking seriously'. ${ }^{52}$ The Committee argued for a chamber that had a composition distinct from the first chamber, adequate powers to perform its roles, and perceived legitimacy to enable it to use those powers. ${ }^{53}$ The Committee also disagreed with both the Royal Commission and the government white paper in terms of maintaining the pre-eminence of the House of Commons. This was something of a red herring for the Committee, which argued that 'no-one is casting any doubt on that preeminence' and that the task should instead be to enhance the effectiveness and capacity of parliament as a whole. ${ }^{54}$

The evidence received by the Public Administration Committee during its investigation demonstrates the controversy associated with issues of representation, 
democracy and legitimacy with respect to second chamber reform. Baroness Williams of Crosby, for example, observed that 'there is by the electorate a growing feeling that if you have no substantial elected second chamber it does not have the legitimacy or validity it should have. ${ }^{55}$ Nevertheless, Baroness Williams defended a small appointed element so as to ensure the inclusion in the chamber of those individuals with specialist knowledge, and whose contribution would not be fully utilised by simply giving expert evidence to Lords' select committees. ${ }^{56}$ In this regard, Baroness Williams is highlighting the difficulties of securing a chamber that is democratic while also possessing certain representational qualities, and stressing the merits of the different types of input legitimacy that the reformed second chamber might in theory exhibit. There was also much discussion during the course of the oral evidence about the optimum proportion of elected members, with Mark Fisher MP, for example, insisting that the democratic nature of the chamber was the most important aspect of reform. He noted that, '[h]aving put a lot of our eggs in the democratic accountability elected basket, I think that to go much below two-thirds [elected proportion] would start to look just a bit like a sell-out. ${ }^{57}$ From this perspective, input legitimacy is the most crucial consideration.

Professor Lord Norton of Louth outlined his view quite differently. His opinion was that the 'present arrangements' of the chamber were 'very appropriate' because it 'delivers benefits and I think once you move in the direction of election, you start to deliver disbenefits to the political system. ${ }^{58}$ Lord Norton further argued that, "the legitimacy of the House of Lords has to be earned, we cannot take it as a given,' and that, in order to earn that legitimacy the chamber has to work for it, which requires 'a house of experience and expertise' geared towards fulfilling specific functions. ${ }^{59}$ In prioritising the outputs of the political system, and the corresponding output legitimacy 
that these confer, the central concerns involve how attempts to alter the input legitimacy of the system (by means of election) will impact upon the output legitimacy. If it is the output legitimacy of the second chamber that is of most importance, the conclusion may be that only a focus on the representational, rather than democratic, aspects of the House will preserve that legitimacy. For Lord Norton, '[1] egitimacy ... does not derive solely from election ... [w]e are a legitimate chamber for fulfilling the functions that we have. $^{, 60}$

This was a view shared by the then Lord Chancellor, Lord Irvine of Lairg, who was intimately involved in the reform programme at the time. He argued that the second chamber's scrutinising capabilities should be preserved in the reform process because they added value to the system, and that any elected element should be of a size that did not threaten those skills. ${ }^{61}$ Once more, output legitimacy is argued to be of greater relevance than input legitimacy. Lord Irvine also stressed that he 'did not accept that the House of Lords is illegitimate because of how it is composed. ${ }^{62}$ In justifying the inclusion of a small elected element, the Lord Chancellor explained that, ' $[\mathrm{t}]$ he concept was not to add to the legitimacy of the House of Lords, which I would say would be of equal legitimacy were it to be fully nominated, but to ensure that there were people with real experience of the life and politics of the regions there. ${ }^{63}$ Yet Lord Irvine is conflating two distinct issues here. The inclusion of regional members is justified with reference to the need for a particular kind of representative role for the House, and not with reference to arguments about democracy. Furthermore, Lord Irvine fails to explain how nominated and elected members could be of 'equal legitimacy'. Such input legitimacy would stem from whether or not these different types of members would be considered justified by the electorate: it is not clear that both types would indeed be considered equally legitimate. 
However, for the Public Administration Committee, arguments regarding the extent of the second chamber's output legitimacy were insufficient. It stated that, 'there is ample evidence that, for all its expertise and experience, it does not have enough confidence in its own legitimacy. ${ }^{64}$ As such, 'a second chamber that is more legitimate will perform its role and exercise its powers with more confidence. ${ }^{65}$ By suggesting that legitimacy primarily means input legitimacy, and the extent to which the chamber can be classed as democratic, the Committee thus distinguish 'between the overall legitimacy of the institution and the legitimacy of individual members.' Consequently, 'the former does require a sufficiently firm basis in election, or the institution will never be taken seriously enough; but that once this is established there need be no difference in legitimacy between members drawn from different sources. ${ }^{66}$ The Committee favoured a predominantly elected chamber, on the basis that 'the legitimacy of the institution requires it', because otherwise 'the chamber will not be as effective as it needs to be. ${ }^{67}$ The input legitimacy enjoyed by the chamber, therefore, is paramount, and dependent on it possessing democratic criteria, which has a direct impact on output legitimacy. The Committee recommended a chamber that was 60 per cent elected, 20 per cent nominated by political parties, and 20 per cent independent nominees. ${ }^{68}$ However, the Committee fails to justify its argument that there would be no difference in legitimacy between members drawn from different sources. Territorial representation is the traditional method of British parliamentary representation, and the Committee does not explain why territorially elected members of the second chamber would not consider themselves (or be considered by the electorate) as more legitimate than members who had been appointed, regardless of the representational attributes such members contributed to the house. 


\section{The Joint Committee on Reform of the House of Lords}

Sustained criticism of the government's November 2001 white paper from both inside and outside the Parliamentary Labour Party, focused predominantly on the proportion of directly elected members it advocated, forced the government to abandon its recommendations. ${ }^{69}$ It subsequently established a Joint Committee of the two Houses of Parliament to explore the matter, its remit being to bring forward options for the composition of the second chamber. ${ }^{70}$ The Committee's report, published in December 2002, outlined five qualities that it wished to see in the reformed upper house: legitimacy, representativeness, no domination by any one party, independence, and expertise. ${ }^{71}$ As with the Royal Commission report, it is notable that there is no specific mention of a desire to see democratic qualities in the reformed house. The Joint Committee also had similar terms of reference to the Royal Commission, which included the requirement to consider the impact of proposed changes on the preeminence of the House of Commons. ${ }^{72}$

The Committee argued that '[t]he lack of representativeness of the hereditary House gradually diminished its authority in the twentieth century. ${ }^{73}$ In this respect, the Committee shares the view of the Royal Commission, 'that increased representativeness will enhance the legitimacy of the House of Lords.' The Committee believed that, in terms of the desirable qualities for the second chamber, the House of Lords was 'weakest in respect of representativeness', and the Committee focused much of its attention on this point. ${ }^{74}$ Enhanced representativeness could be secured either by a system of appointments or elections, so long as 'appropriate checks' were in place. ${ }^{75}$

The Committee outlined seven different options for reform, and examination of these options demonstrates the degree of conceptual conflation that existed, particularly with reference to the issue of legitimacy. For the Committee, a fully appointed house 
would most fully realise its goals for a more representative chamber, and also facilitate the inclusion of the independent members and experts that were deemed valuable to the work of the House. ${ }^{76}$ However, the Committee also noted the possibility that the legitimacy of such a House would be challenged', ${ }^{77}$ indicating an understanding that democracy, and the system of elections at its heart, is the most crucial component for institutional legitimacy. However, the report also states that such a challenge could be 'mitigated' if the proposed Appointments Commission was independent, statutory, and thus respected. There is some confusion on this matter. On the one hand, the Committee noted that the undemocratic nature of an appointed house could attract criticism because it would not be considered legitimate, but then countered this possibility by way of an exemplary appointments process. However, if the Committee believed that the legitimacy of the institution could be challenged on democratic grounds, this logically suggests the need for the chamber to have democratic characteristics, rather than a need to change the procedures of the undemocratic composition method.

Further confusion exists in the discussion of the merits of a fully elected House. The Committee stated that '[t]he principal argument in favour of a fully elected House is that it would have greater legitimacy and accountability. That view rests upon the premise that legitimacy and accountability are conferred by election. ${ }^{78}$ The report goes on to say that, '[o]n the other hand the existing House, in exercising independence and in applying expertise, has contributed significantly to the process of parliamentary scrutiny. ${ }^{, 79}$ This is a clear statement about the nature of input and output legitimacy. Of the contribution made by the House to scrutiny, the report says '[t]hat may also be considered a basis of legitimacy, important but different from legitimacy conferred by election. ${ }^{80}$ The Committee is right to note that there are different bases of legitimacy, and that each is important. But this is in conflict with the statements made about the 
merits of an appointed chamber, where the report noted that 'the legitimacy of such a House would be challenged.' In that instance, the Committee was clear that legitimacy is linked with democracy, but made no real distinction between input and output legitimacy, and did not note that an appointed chamber could still possess output legitimacy even if its input legitimacy was perceived as questionable.

Confusion is also evident during the discussion of the mixed models. For example, the report notes that, with the 60 per cent appointed / 40 per cent elected option, the elected proportion would 'go some way to meet the demands of legitimacy. ${ }^{81}$ Legitimacy once more has become linked primarily to democracy. Yet throughout the discussions of the mixed models, constant, if inadvertent, reference is made to both input and output legitimacy, as the report balances the respective merits of different proportions of appointed and elected members, and what they can contribute in terms of representativeness and to the work of the House. What remains largely unexamined is the complex relationship between input and output legitimacy. Competing claims about the impact that a democratically constituted second chamber would mean for both input and output legitimacy, and its impact on the lower house, contributed to the lack of support for any one of the options forwarded.

\section{The future of reform}

Until recently, the reform process was stalled following the failure of the House of Commons to support one of the seven options for reform in February 2003. In September 2003, the government announced plans to remove the remaining hereditary peers and establish the Appointments Commission on a firmer footing. ${ }^{82}$ By then, the proposal to make the Lords 'more democratic and more representative' had been

replaced with a desire to make it "more legitimate and more representative. ${ }^{83}$ This shift 
in linguistic emphasis demonstrates the difficulties experienced by the Labour government in wishing to see a 'more democratic' second chamber while struggling with the implications of an elected membership. By 2003, an attempt was made to divorce legitimacy from democracy, and thus to associate input legitimacy only with the representativeness of the chamber. The government announced in March 2004 that it would not proceed with these plans, largely the result of division within the PLP. In its 2005 manifesto, the government pledged to examine the powers of the second chamber, particularly the length of time the Lords can spend debating legislation. ${ }^{84}$ This change in emphasis was partly informed by a report from the Working Group of Labour Peers, which argued that the roles and powers of the second chamber had to be examined in advance of any alteration to the composition. ${ }^{85}$ Given the difficulties that have plagued attempts to find consensus on a reformed composition, the government hoped reform could be secured by simply reducing the powers of the upper house.

Nevertheless, the issue of composition did not disappear, nor did the debates surrounding the respective merits of a representative chamber and a democratic chamber, and what each means for institutional legitimacy. In February 2005, a private members' bill was published, supported by key MPs such as Paul Tyler (now Lord Tyler), Sir George Young and the late Robin Cook, which proposed a 70 per cent elected House with an Appointments Commission choosing the remaining 30 per cent. ${ }^{86}$ The proposals were defended in a lengthy pamphlet, ${ }^{87}$ in which the authors shared the view of the Public Administration Committee that arguments for preserving the preeminence of the House of Commons were overstated, and that the legitimacy of the second chamber was largely dependent on it having democratic characteristics. The pamphlet argued that incorporating a partially appointed membership prevented any claim to equal legitimacy, ${ }^{88}$ and dismissed concerns about potential tensions between 
appointed and elected members, as had the Royal Commission, by noting that the chamber had long had a mixed membership. ${ }^{89}$ However, the pamphlet said nothing about the possibility that the lack of tension in a chamber composed of different kinds of unelected memberships might not be replicated in one containing both elected and unelected individuals. The bill fell at the dissolution of parliament prior to the 2005 general election, but was subsequently supported in EDM 571, tabled in July 2005, which called for a predominantly elected second chamber, and which, at the time of writing, had attracted 118 signatures. ${ }^{90}$

House of Lords reform was recovered from the constitutional long grass in spring 2006 by the 'loans for peerages' controversy, which prompted demands that the composition of the chamber be overhauled so as to remove the power of patronage from decisions about its membership. Although the parties remain internally divided about which compositional arrangements to support, cross-party talks were proceeding at the time of writing, geared towards producing legislation and a free vote in the House of Commons before the end of 2006. The same kind of conceptual conflation and confusion that has thus far characterised debate over House of Lords reform is likely to remain a prominent feature of this debate. Consequently, there are several conclusions to be drawn about the nature of the reform discourse since 1997, which are of relevance for any continuing discussion on the matter.

Perhaps the most obvious, and indeed encouraging, conclusion is that reform actors have held clear ideas about what they mean by representation and representativeness in the second chamber, and how particular kinds of representation will impact upon the functional capacities of the house. The reform proposals explored all noted the need for there to be elements of independence and expertise in the house, along with varying degrees of regional representation, and also that the house needed to 
be more representative of identities such as gender and ethnicity. The reports also argued that a more representative chamber would be justifiably more legitimate than the current house, and that the inclusion of certain kinds of representative would enable it to maintain its contribution to parliamentary scrutiny. A clear link was thus made between input legitimacy and output legitimacy.

However, what was more problematic was the way these reports treated the issue of democracy in the second chamber, and the contribution of democratic legitimacy. The discussions oscillated between (often inadvertently) treating democratic legitimacy as the only type of legitimacy, and declaring it to be only one route to institutional legitimacy. Several reports, while acknowledging the value of democratic legitimacy, nevertheless pointed to the outputs of the chamber as an equally valid type of legitimacy. The problem with these discussions becomes plain by referring to Beetham's analysis. He stated that legitimacy is not an all-or-nothing affair, that there are degrees of legitimacy, and that there is a need to distinguish between input and output legitimacy. We must therefore examine whether or not the rules and organisation of an institution are considered by the public to be justifiable. With regards to the House of Lords, does the public consider a fully appointed house to be justifiable? Does it consider a mixed house to be justifiable? Are the rules of appointment acceptable? What is at issue is whether the structural and organisational principles on which the chamber is based are justified in terms of accepted beliefs held by the public. If there is doubt over the justifications for the chamber's composition, that will impact upon the input legitimacy that it enjoys.

Many of those involved in the reform debate have insisted that the most important legitimacy concern is that the reformed house fulfils its functions properly and makes a relevant contribution to public life. This conforms to the output legitimacy described by 
Beetham, in that an institution should fulfil the needs, and respect the values, of the public. But this in itself cannot 'make' an institution legitimate, because it is not only about output. If the public believe they have no control, or only limited control, over an institution, and that they cannot identify with it, this may also impact upon its legitimacy. The degree of legitimacy enjoyed by an institution stems from these three different sources, and a high degree of legitimacy in one area may not compensate for low levels elsewhere. The House of Lords has long attracted commendation for its work, and for the added value it brings to the system of parliamentary scrutiny. It has, therefore, possessed a degree of output legitimacy for quite some time, an output legitimacy that actors have been keen to preserve in the reformed house. However, that output legitimacy has not stopped the institution being criticised for its undemocratic nature, and both its hereditary and appointed composition have been the focus of complaint. It may therefore remain the case that a reformed house will continue to be criticised if it is undemocratic, regardless of its contribution to fulfilling various parliamentary functions. Until some scheme for reform is actually implemented, however, it is difficult to predict with any real certainty how the public will rate the input and output legitimacy of the reformed second chamber.

Of course, people often offer inconsistent opinions of what they want from a reformed House, and the Royal Commission received many responses to its public consultation that suggested people wanted to preserve independence and expertise but also wanted an elected chamber. ${ }^{91}$ The task of institutional design is not an easy one, nor is the struggle to find a balance between representational and democratic criteria. What may well have to change, however, are the justifications used to defend different composition options. Schemes cannot be justified with reference to democratic legitimacy if they fail to encompass democratic criteria such as elections. It is unclear 
where this leaves the mixed compositions. Is a 60 per cent elected house more democratic than a 50 per cent elected house? The arguments forwarded by some actors suggest yes, although without much real explanation as to why, with the inference simply being that it is a matter of quantity (in which case, for the house to be democratic, should it not contain a wholly elected membership?). Also missing has been any account about why territorially elected members would not consider themselves more legitimate than appointed members. Simply saying that they will all be equally legitimate is insufficient. Those involved in supplying schemes for Lords' reform must be clearer about the basis on which those plans can confer legitimacy, and the extent to which they possess democratic credentials. Until that happens, interested observers of the debate are going to be understandably confused, notably over the reticence of many actors with regards to supporting a chamber that possesses democratic legitimacy. What is required is more transparent discussion of the balance between institutional input and output legitimacy, and the degree to which the reformed chamber would be considered to possess each kind. What must perhaps be dispensed with is the desire to incorporate some elusive ideal of both representativeness and democracy into the chamber, an incorporation which involves different members being included on different bases in an effort to cloak the chamber in a 'generic' legitimacy. Institutional legitimacy is not generic, but is instead specific, justifiable and gradated: until this is more clearly articulated in the debate over House of Lords reform, the various options forwarded for the chamber's composition will remain replete with the kinds of inconsistencies and confusions that have thus far dogged this particular strand of constitutional discourse.

\section{$\underline{\text { Notes }}$}

\footnotetext{
${ }^{1}$ I would like to acknowledge the receipt of an ESRC Postdoctoral Fellowship (award PTA-026-271021), held at the University of Strathclyde August 2005 - July 2006, which made this article possible.
} 
Thanks also to the anonymous referees, and to David Judge, for their comments on earlier versions of the article: the usual disclaimer applies.

${ }^{2}$ H. Pitkin, The Concept of Representation, University of California Press, 1967,p.8-9; original emphasis.

${ }^{3}$ D. Judge, Representation: Theory and Practice in Britain, Routledge, 1999, p.149.

${ }^{4}$ D. Judge, The Parliamentary State, Sage, 1993.

${ }^{5}$ G.D.H. Cole, Guild Socialism Restated, Leonard Parsons, 1920.

${ }^{6}$ Winston Churchill's Romanes Lecture at Oxford University, 'Parliament and the Economic Problem', in R.R. James (ed.), Winston S. Churchill: His Complete Speeches, 1896-1963, Chelsea House Publishers, 1974; and Churchill's evidence to the 1931 Procedure Committee, HC 161, Special Report from the Select Committee on Procedure in Public Business, HMSO.

${ }^{7}$ D. Judge, Representation, p.22-23.

${ }^{8}$ A. Phillips, The Politics of Presence, Clarendon Press, 1995.

${ }^{9}$ D. Judge, Representation, p.8-9.

${ }^{10}$ P. Hirst, Representative Democracy and its Limits, Polity Press, 1990, p.4.

${ }^{11}$ D. Judge, Representation., p.9.

${ }^{12}$ Ibid., p. 10.

${ }^{13}$ G. Sartori, The Theory of Democracy Revisited, Chatham House, 1987, p.30.

${ }^{14}$ R. Dahl, Democracy and its Critics, Yale University Press, 1989, p.108-114.

${ }^{15}$ P. Hirst, p. 28.

${ }^{16}$ D. Beetham, The Legitimation of Power, Palgrave 1991, p.11.

${ }^{17}$ Ibid., p.11, original emphasis.

${ }^{18}$ D. Beetham \& C. Lord, Legitimacy in the European Union, Longman, 1998, p.9.

${ }^{19}$ D. Beetham, The Legitimation of Power, p. 16.

${ }^{20}$ Ibid., p. 159.

${ }^{21}$ Ibid., p.159.

${ }^{22}$ Ibid., p. 159.

${ }^{23}$ C. Lord \& D. Beetham, 'Legitimizing the EU: Is there a 'post-parliamentary basis' for its legitimation?', Journal of Common Market Studies, 2001, vol.39, no.3, p.444.

${ }^{24}$ Ibid., p.444.

${ }^{25}$ D. Beetham \& C. Lord, Legitimacy in the European Union, p.4.

${ }^{26}$ Labour Party, New Labour: Because Britain Deserves Better, 1997.

27 Ibid.

${ }^{28} \mathrm{Cm}$ 4534, A House for the Future: Report from the Royal Commission on Reform of the House of Lords, HMSO, 2000, p.96.

${ }^{29}$ Ibid., p.97.

${ }^{30}$ Ibid., p.97.

${ }^{31}$ Ibid., p.97.

${ }^{32}$ Ibid., p.97.

${ }^{33}$ Ibid., p.98.

${ }^{34}$ Ibid., p.99.

${ }^{35}$ Ibid., p.100-101.

${ }^{36}$ Ibid., p. 106.

37 The Commission report outlined three different models for electing the regional members: at the general election, chosen by complementary election; or at the European Parliament elections (there were two different versions of this method).

${ }^{38} \mathrm{Cm} \mathrm{4534, \text {p. } 1 1 5 .}$

${ }^{39} \mathrm{Cm}$ 5291, The House of Lords: Completing the Reform, HMSO, 2001.

${ }^{40}$ Ibid., para.8.

${ }^{41}$ Labour Party, Ambitions for Britain, 2001.

${ }^{42}$ Cm 5291, para.64.

${ }^{43}$ Ibid., para.35.

${ }^{44}$ Ibid.

${ }^{45}$ Ibid., para.36.

${ }^{46}$ Ibid., para. 37.

${ }^{47}$ Ibid., para.42.

${ }^{48}$ Ibid., para.38.

${ }^{49}$ Ibid., para. 17.

${ }^{50} \mathrm{HC}$ 494, The Second Chamber: Continuing the Reform, HMSO, 2002.

${ }^{51}$ Ibid., para.6. 
${ }^{52}$ Ibid., para.7.

${ }^{53}$ Ibid., para. 8 .

${ }^{54}$ Ibid., para.36.

${ }^{55}$ HC 494, Minutes of Evidence, 10 January 2002, Q.74.

${ }^{56}$ Ibid., Q.88.

${ }^{57}$ Ibid., Q.293.

${ }^{58}$ Ibid., Q.131.

${ }^{59}$ Ibid., Q.165.

${ }^{60}$ Ibid., Q.168.

${ }^{61}$ Ibid., Q.388.

${ }^{62}$ Ibid., Q.402.

${ }^{63}$ Ibid., Q.413.

${ }^{64} \mathrm{HC} 494$, para.60.

65 Ibid., para.68.

${ }^{66}$ Ibid.

${ }^{67}$ Ibid., para.94.

${ }^{68}$ Ibid., para.96.

${ }^{69}$ See for example, R. Cook, The Point of Departure, Simon \& Schuster, 2003, p.52; Early Day Motion 226, 2001-2002 (which called for a higher proportion of elected members, and already listed 149 signatures when the government's white paper was debated in November 2001); and business questions at HC Debs., vol.374, cols.240-250.

${ }^{70}$ Such a Joint Committee had been promised in the 1997 Labour Party manifesto, but the Royal Commission had been established in its place.

${ }^{71}$ HC 171, House of Lords Reform, HMSO, 2002, para.30.

${ }^{72}$ Ibid., terms of reference.

${ }^{73}$ Ibid., para.16.

${ }^{74}$ Ibid., para.33.

${ }^{75}$ Ibid.

${ }^{76}$ Ibid., paras.64-65.

${ }^{77}$ Ibid., para.63.

${ }^{78}$ Ibid., para.67.

${ }^{79}$ Ibid.

${ }^{80}$ Ibid.

${ }^{81}$ Ibid., para.72.

${ }^{82}$ CP 14/03, Constitutional Reform: Next Steps for the House of Lords, HMSO, 2003.

${ }^{83}$ Ibid., introduction.

${ }^{84}$ Labour Party, Britain Forward, Not Back, 2005.

${ }^{85}$ See HL Debs., 26 January 2005, vol.668, col.1331.

${ }^{86}$ HC Debs., 10 February 2005, vol.430, col.1679.

${ }^{87}$ P. Tyler, K. Clarke, R. Cook, T. Wright, G. Young, Reforming the House of Lords: Breaking the Deadlock, Constitution Unit, London, 2005.

${ }^{88}$ Ibid., pp.9-11.

${ }^{89}$ Ibid., p. 18.

${ }^{90}$ EDM 571, House of Lords Reform, 2005/06.

${ }^{91}$ Cm 4534 op.cit.; M. Wheeler-Booth, 'The House of Lords,' in R. Blackburn \& A. Kennon, Parliament: Functions, Practice and Procedures, Sweet \& Maxwell, 2003. 